\title{
PENERAPAN SANKSI PIDANA TA'ZÎR BAGI PELAKU TINDAK PIDANA KORUPSI DI INDONESIA
}

\author{
Endang Jumali \\ STAI Surya Kencana Cianjur \\ E-Mail: endang_jumali@yahoo.com
}

\begin{abstract}
Corruption is a criminal act which is getting the attention of many people. So, it need to get attention from the perspective of Islamic Criminal Law, both conceptually and operationally. Therefore, this paper is not only describe the historical development of concepts and theories of Islamic criminal law relating to the criminal law of corruption, but also specifically explained about nazhariyyah al-ta'zîr criticism in legal theory of Ta'zîr to the Law 20 of 2001 on the Eradication of Corruption. The main purpose of this article is to provide an overview of the theoretical possibility of ta'zîr sanctions for perpetrators of corruption in Indonesia through nazhariyyah al-ta'zîr and its relevance to the Law Number 20 Year 2001 on Eradication of Corruption.
\end{abstract}

\begin{abstract}
Abstrak
Korupsi merupakan perilaku tindak pidana yang mendapatkan perhatian banyak pihak, sehingga perlu mendapatkan pembahasan yang memadai dari perspektif hukum pidana Islam baik secara konsepsional maupun operasional. Oleh karena itu, tulisan ini bukan hanya menjelaskan tentang sejarah perkembangan konsep dan teori-teori hukum pidana Islam yang berkaitan dengan hukum pidana korupsi, tetapi secara spesifik juga menjelaskan tentang kritik nazhariyyah al-ta'zîr dalam teori hukum ta'zîr terhadap Undang-Undang 20 Tahun 2001 Tentang Pemberantasan Tindak Pidana Korupsi. Tujuan utama ditulisnya artikel ini adalah untuk memberikan gambaran teoritis tentang kemungkinan penerapan sanksi pidana ta'zîr bagi pelaku tindak pidana korupsi di Indonesia melalui nazhariyyah al-ta'zîr dan relevansinya dengan Undang-Undang Nomor 20 Tahun 2001 Tentang Pemberantasan Tindak Pidana Korupsi.
\end{abstract}

Kata Kunci:

Korupsi, Sanksi Pidana Ta'zîr, Transformasi, Hukum

\section{A. Pendahuluan}

Indonesia merupakan salah satu negara dengan jumlah populasi penduduk mayoritas beragama Islam terbesar di dunia, yang mana hukum Islam menjadi bagian sistem hukum yang hidup dan berlaku di dalamnya. Namun, mengapa negeri yang disebut mayoritas beragama Islam terbesar dan menjunjung tinggi nilai-nilai spiritual ini justru diposisikan pada peringkat pertama sebagai negara terkorup di Asia dan dianggap paling lamban keluar dari krisis multidimensi, terutama dibandingkan dengan negara-negara tetangganya.

Hingga saat ini, korupsi di Indonesia memang dalam kondisi yang sangat mengkha- watirkan. Negara dengan lebih dari 240 juta penduduk ini, pada tahun 2004 tercatat sebagai negara ke-5 terkorup di dunia dari 146 negara dan bahkan akhir-akhir ini diposisikan sebagai negara pertama terkorup di Asia. Peringkat yang baru dikeluarkan Transparansi Internasional Tahun $2011^{1}$ tersebut menunjukkan bahwa Indonesia satu tingkat lebih

${ }^{1}$ Transparansi International Indonesia (TII) merupakan salah satu Organisasi Non Pemerintah (NGO) dan mitra kerja dari Indonesian Cooruption Watch (ICW) yang berkedudukan di Jakarta dan sama-sama fokus terhadap kebijakan publik di bidang transparansi keuangan negara serta pemberantasan korupsi. 
buruk dari peringkat tahun lalu. ${ }^{2}$ Pertanyaannya, mengapa dalam suatu negara muslim seperti Indonesia, di mana hukum Islam itu berlaku, korupsi justru tumbuh subur dan sulit diberantas.

Dalam khazanah pemikiran hukum Islam (figh) klasik, perilaku korupsi belum memperoleh porsi pembahasan yang memadai. Para fuqaha berbicara tentang kejahatan memakan harta benda manusia secara tidak benar (akl amwâl al-nas bi al-bathil) seperti yang diharamkan dalam al-Quran, tetapi apabila merujuk kepada kata asal dari korupsi (corrupt), maka dapat berarti merusak (dalam bentuk kecurangan) atau menyuap. Di antara berbagai bentuk kejahatan ini yang nampaknya paling mirip substansinya dengan korupsi ialah ghulûl yang diartikan sebagai pengkhianatan terhadap amanah atau penggelapan dalam pengelolaan harta rampasan perang dan risywah atau yang biasa dikenal dengan istilah suap. ${ }^{3}$ Oleh karena itu, tulisan ini akan menjelaskan kemungkinan penerapan sanksi pidana ta'zîr bagi pelaku tindak pidana korupsi di Indonesia.

\section{B. Beberapa Istilah Teknis Tentang Korup- si dalam Hukum Islam}

Asal-usul kata korupsi, menurut banyak pendapat, diadopsi dari bahasa Inggris yaitu corruption. Geneologi atau asal-asul kata korupsi berasal dari bahasa Latin, yakni corruptio atau corruptus. Kata corruptus itu sendiri berasal dari kata dasar corrumpere, yang tersusun dari kata com (yang berarti menyeluruh) dan kata rumpere (yang berarti kerusa-

${ }^{2}$ Koran Tempo, Pemberantasan Korupsi dari Masa ke Masa, Edisi Kamis, 18 Desember 2003, lihat pula dalam http://www.tempointeraktif.com/hg/narasi/2004/1o/25/nrs, 20041025-01,id.html, diakses tanggal 16 Desember 2009.

${ }^{3}$ Lexi Zulkarnaen mengutip beberapa pengertian korupsi dari John M. Echols dan Hassan Shadily, Kamus Inggris Indonesia; An English-Indonesian Dictionary (Jakarta: Gramedia. 2003), cet. ke-25, hlm. 149. Soetandyo Wignjosubroto "Korupsi Sebagai Masalah Sosial-Budaya," dalam A.S.Burhan, dkk, ed, Korupsi di Negeri Kaum Beragama; Ikhtiah Membangun Fiqh Anti Korupsi (Jakarta: P3M dan Kemitraan Partnership. 2004), hlm. 99. Dan Azyumardi Azra, Agama dan Pemberantasan Korupsi, artikel, lihat dalam http://www.kompas.com/kompas-cetak/0309/05/ opini/542015.htm, diakses pada tanggal 16 Desember 2009. kan secara total kepercayaan khalayak kepada si pelaku yang tidak jujur). ${ }^{4}$

Dalam Kamus Bahasa Belanda Hukum dikenal istilah corruptie, yang kemudian diserap menjadi kata baku dalam bahasa Indonesia, yang berarti merusak habis-habisan. Sedangkan dari segi istilah, korupsi dapat dimaknai sebagai tingkah laku individu yang menggunakan wewenang dan jabatan untuk keuntungan pribadi, serta berakibat merugikan kepentingan umum dan negara. Bentuk nyata dari tindakan korupsi berwujud penggelapan, penyuapan, penyogokan, manipulasi data administrasi keuangan, dan perbuatan sejenis lainnya. ${ }^{5}$

Syed Hussein Alatas ${ }^{6}$ menjelaskan bahwa hakikat korupsi adalah suatu tindakan pidana pencurian yang dilakukan melalui penipuan dalam situasi yang mengkhianati kepercayaan orang lain. Sedangkan Andi Ham$z^{2}{ }^{7}$ mendefinisikan korupsi sebagai perbuatan buruk, busuk, bejat, suka disuap, perbuatan menghina atau memfitnah, menyimpang dari kesucian, dan tidak bermoral. Kemudian dalam Webster's Third New International Dictionary, korupsi didefinisikan sebagai ajakan (dari seorang pejabat publik) dengan pertimbangan-pertimbangan yang tidak semestinya untuk melakukan pelanggaran tugas. ${ }^{8}$ Sedangkan dalam Kamus Besar Bahasa Indonesia ${ }^{9}$ disebutkan bahwa korupsi adalah suatu tindakan pidana penyelewengan atau penggelapan uang negara atau perusahaan

${ }^{4}$ Adami Chazawi, Hukum Pidana Materiil dan Formiil Korupsi di Indonesia (Malang: CV. Bayu Media. 2005), hlm. 1. Bandingkan dengan Soetandyo Wignjosubroto , Korupsi Sebagai Masalah Sosial-Budaya, dalam A.S.Burhan, dkk, ed, Korupsi Di Negeri Kaum Beragama; Ikhtiah Membangun Figh Anti Korupsi (Jakarta: P3M dan Kemitraan Partnership. 2004), hlm. 99.

${ }^{5}$ Lexi Zulkarnaen Hikmah, Korupsi Perspektif Hadits, artikel dalam http://www. kommabogor.wordpress.com/2008/01/13/korupsi-perspektif-hadis/, diakses pada tanggal 28 Maret 2010.

${ }^{6}$ Ahmad Wardi Muslich, Hukum Pidana Islam (Jakarta: PT. Sinar Grafika. 2004), hlm. 5.

${ }^{7}$ Andi Hamzah, Pemberantasan Korupsi Melalui Hukum Nashional dan Internashional (Jakarta: PT. Raja Grafindo Persada. 2005), hlm. 4.

${ }^{8}$ Editor, Webster's Third New International Dictionary (USA: Webster University Press. 2000), hlm. 173 .

${ }^{9}$ W.J.S. Poerwadarminta, Kamus Besar Bahasa Indonesia (Jakarta: Balai Pustaka. 2001), hlm. 462. 
dan sebagainya yang digunakan untuk keuntungan pribadi atau orang lain.

Dalam khazanah pemikiran hukum Islam (fiqh) klasik, perilaku korupsi belum memperoleh porsi pembahasan yang memadai, ketika para fuqaha berbicara tentang kejahatan memakan harta benda manusia secara tidak benar (akl amwâl al-nas bi al-bathil) seperti yang diharamkan dalam al-Quran, tetapi apabila merujuk kepada kata asal dari korupsi (corrupt), maka dapat berarti merusak (dalam bentuk kecurangan) atau menyuap. Di antara berbagai bentuk kejahatan ini yang nampaknya paling mirip substansinya dengan korupsi ialah ghulûl yang diartikan sebagai pengkhianatan terhadap amanah dalam pengelolaan harta rampasan perang dan risywah atau yang biasa dikenal dengan istilah suap.

Dalam konteks ajaran Islam yang lebih luas, korupsi merupakan tindakan yang bertentangan dengan prinsip keadilan (al-'adalah), akuntabilitas (al-amanah), dan tanggung jawab. Korupsi dengan segala dampak negatifnya yang menimbulkan berbagai distorsi terhadap kehidupan negara dan masyarakat dapat dikategorikan termasuk perbuatan $\mathrm{fa}$ sad yang diatur melalui hukuman ta'zîr, karena telah melakukan kerusakan di muka bumi yang bertentangan dengan syari'at.

Dalam kajian hukum pidana Islam, istilah ta'zîr secara bahasa merupakan mashdar (kata dasar) dari 'azzaro yang berarti menolak dan mencegah kejahatan, juga berarti menguatkan, memuliakan, membantu. Ta'zîr juga berarti hukuman yang berupa memberi pelajaran. Di sebut dengan ta'zîr, karena hukuman tersebut sebenarnya menghalangi si terhukum untuk tidak kembali kepada jarimah atau dengan kata lain membuatnya jera.

Sementara para fuqaha' mengartikan ta'zîr dengan hukuman yang tidak detentukan oleh al-Quran dan hadits yang berkaitan dengan kejahatan yang melanggar hak Allah dan hak hamba yang berfungsi untuk memberi pelajaran kepada si terhukum dan mencegahnya untuk tidak mengulangi kejahatan serupa. Ta'zîr sering juga disamakan oleh fuqaha dengan hukuman terhadap setiap maksiat yang tidak diancam dengan hukuman had atau kafarat. ${ }^{10}$

Bisa dikatakan pula bahwa ta'zîr adalah suatu jarimah yang diancam dengan hukuman ta'zîr (selain had dan qishâsh), pelaksanaan hukuman ta'zîr, baik yang jenis larangannya ditentukan oleh nas atau tidak, baik perbuatan itu menyangkut hak Allah atau hak perorangan, hukumannya diserahkan sepenuhnya kepada penguasa. Hukuman dalam jarimah ta'zîr tidak ditentukan ukurannya atau kadarnya, artinya untuk menentukan batas terendah dan tertinggi diserahkan sepenuhnya kepada hakim (penguasa).

Berkenaan dengan hal tersebut, para pemikir membagi tiga istilah hukum Islam yang maknanya dekat dengan korupsi dalam pembahasan nazhariyyah al-ta'zîr, yakni ghulûl, risywah, ghasab, hirabah, khianat, dan sarîqah, sebagaimana penjelasan berikut ini: ${ }^{11}$

Pertama, ghulûl menurut bahasa adalah khianat, sedangkan menurut Ibn al-Atsir, ghulûl adalah berkhianat mengenai harta rampasan perang atau mencuri harta tersebut, dan masih menurutnya setiap orang yang berkhianat secara sembunyi-sembunyi mengenai urusan sesuatu, maka ia telah berbuat ghulûl. Adapun maksud dari ghulûl menurut korupsi adalah berupa tindakan penggelapan yang dilakukan seseorang untuk memperkaya diri sendiri. Kemudian ada pula yang menganggap harta ghulûl adalah harta yang diperoleh oleh pejabat (pemerintah atau swasta) melalui kecurangan atau tidak syar'i, baik yang diambil harta negara maupun masyarakat.

Kedua, risywah, menurut terminologi fiqh, risywah (suap) adalah segala sesuatu

\footnotetext{
${ }^{10}$ Penulis mengutip definisi ta'zîr dari http://zanikhan.multiply.com/journal/item/694/694, diakses tanggal 18 Oktober 2012.

${ }^{11}$ Penulis mengutip ontologi korupsi dengan mengacu kepada tulisan Lexi Zulkarnaen mengutip beberapa pengertian korupsi dari John M. Echols dan Hassan Shadily, Kamus Inggris Indonesia; An EnglishIndonesian Dictionary (Jakarta: Gramedia. 2003), cet. ke-25, hlm. 149. Soetandyo Wignjosubroto, Korupsi Sebagai Masalah Sosial-Budaya, dalam A.S.Burhan, dkk, ed, Korupsi Di Negeri. Hlm. 99. Dan Azyumardi Azra, Agama dan Pemberantasan Korupsi, lihat dalam http://www.kompas.com/kompas-cetak/0309/05/opini/542015.htm, diakses tanggal 16 Desember 2007.
} 
yang diberikan oleh seseorang kepada seorang hakim atau yang bukan hakim agar ia memutuskan suatu perkara untuk (kepentingan)nya atau agar ia mengikuti kemauannya. Sedangkan menurut Ibnu Nadim, risywah adalah segala sesuatu yang diberikan seseorang kepada hakim atau yang lainnya untuk memutuskan suatu perkara atau membawa (putusan tersebut) sesuai dengan keinginannya (yang memberi). Risywah (suap) merupakan perbuatan yang dilaknat oleh Allah dan Rasulnya sebagaimana dijelaskan dalam hadis.

Ketiga, ghasab berasal dari kata kerja yang berarti mengambil sesuatu secara paksa dan zalim. Secara istilah, ghasab dapat diartikan sebagai upaya untuk menguasai hak orang lain secara permusuhan/terang-terangan. Ghasab adalah mengambil harta atau menguasai hak orang lain tanpa izin pemiliknya dengan unsur pemaksaan dan terkadang dengan kekerasan serta dilakukan dengan cara terang-terangan. Karena ada unsur terang-terangan, maka ghasab berbeda dengan pencurian dimana salah satu unsurnya adalah pengambilan barang secara sembunyi-sembunyi. Para ulama telah sepakat bahwa ghasab merupakan perbuatan yang terlarang dan diharamkan.

Keempat, hirabah adalah aksi seseorang atau sekelompok orang dalam negara untuk melakukan kekacauan, pembunuhan, perampasan harta, yang secara terang-terangan dapat mengganggu dan menentang peraturan yang berlaku, perikemanusiaan, dan agama. Hirabah merupakan salah satu bentuk jarimah hudud, yaitu tindak pidana yang jenis, jumlah dan hukumannya ditentukan oleh syariat. Hirabah disebut juga oleh ahli fikih sebagai qath'u at-thariq (menyamun) atau as-sarîqah al-kubra (pencurian besar). Ulama fikih menyebut hirabah sebagai as-sarîqah alkubra, karena hirabah itu merupakah upaya mendapatkan harta dalam jumlah besar dengan akibat yang dapat menyebabkan kematian atau kerganggunya keamanan dan ketertiban. Para ulama memang mempersyaratkan hirabah dengan tindakan-tindakan kekerasan untuk merampas harta, mengganggu keamanan dan mengancam nyawa manusia akan tetapi kekerasan dan gang- guan keamanan yang dimaksud tidak dijelaskan lebih detail. Korupsi seperti hirabah karena ia dapat merusak seperti hirabah, mengganggu stabilitas negara dan mengancam hidup orang banyak akibat kekayaan negara yang digerogotinya.

Kelima, kata khianat berasal dari bahasa Arab (خان يخون) yang artinya sikap ingkarnya seseorang saat diberikan kepercayaan. Bentuk isim, dari kata kerja (خان- يخون) adalah (نائن), yang definisinya dikemukakan oleh alSyawkani yaitu seseorang yang diberi kepercayaan untuk merawat/mengurus sesuatu barang dengan akad sewa menyewa dan titipan, tetapi sesuatu itu diambil dan kha'in mengaku jika barang itu hilang atau dia mengingkari barang sewaan tersebut ada padanya. Sedangkan Wahbah al-Zuhaili mendefinisikan khianat dengan segala sesuatu bersifat melanggar janji dan kepercayaan yang telah dipersyaratkan di dalamnya atau telah berlaku menurut adat kebiasaan, seperti tindakan pembantaian terhadap kaum muslim atau sikap menampakkan permusuhan terhadap kaum muslim. Mayoritas ulama Syafi'iyyah lebih cenderung mengkategorikan korupsi sebagai tindak pengkhianatan, karena pelakunya adalah orang yang dipercayakan untuk mengelola harta kas negara. Oleh karena seorang koruptor mengambil harta yang dipercayakan padanya untuk dikelola, maka tidak dapat disanksi dengan hukuman potong tangan.

Keenam, sarîqah terbentuk dari kata ( سرق (يسرق سرقا yang berarti mengambil harta milik seseorang secara sembunyi-sembunyi dan dengan tipu daya. Secara istilah, sarîqah menurut syara', yang dikemukakan oleh Muhammad Abu Syahbah, adalah pengambilan oleh seorang mukallaf (yang baligh dan berakal) terhadap harta milik orang lain dengan diam-diam, apabila barang tersebut mencapai nishab (batas minimal), dari tempat simpanannya, tanpa ada syubhat dalam barang yang diambil tersebut. Menurut Abdul Qadir Awdah, unsur-unsur sarîqah terdiri dari mengambil barang secara sembunyisembunyi, barang yang diambil berupa harta, harta tersebut milik orang lain, unsur melawan hukum. Sanksi dari jarimah ini telah tercantum secara tersurat dalam dalil al- 
Quran maupun hadits, yang mana sanksi bagi sarîqah dapat dikategorikan ke dalam hukuman hudud yang diancam dengan potong tangan.

Mengacu kepada beberapa istilah tersebut, penulis merumuskan bahwa korupsi adalah perbuatan seseorang untuk mengerjakan sesuatu pekerjaan telah dibayar maka apapun selain itu bukan menjadi haknya dan haram mengambilnya. Begitu juga, jika dia memanfaatkan harta perusahaan atau negara untuk kepentingan pribadinya, dalam hal ini ia telah mengambil sesuatu yang bukan menjadi haknya secara bathil dan haram hukumnya. Misalnya, seorang karyawan menerima souvenir sebuah pulpen, parcel diakhir tahun, amplop yang berisi uang atau uang komisi yang biasanya langsung ditransfer, mengambil harta perusahaan/negara, melakukan mark-up suatu transaksi, dan lain-lain.

\section{Landasan Teoritis Sanksi Pidana Ta'zîr dalam Hukum Islam}

Untuk merumuskan landasan teoritis penerapan sanksi pidana ta'zîr bagi pelaku korusi menurut hukum Islam penting kiranya mengacu kepada ketentuan nash yakni ayatayat hukum dalam al-Quran, hadits-hadits hukum dalam Sunnah, dan hasil ijtihad para ulama mujtahid yang telah merumuskan prinsip-prinsip dan asas-asas hukum pelarangan korupsi. Oleh karena itu, dalam ruang lingkup studi hukum Islam, perumusan norma-norma hukum pelarangan korupsi dapat ditemukan dari sumber hukum Islam yang qath'i atau dalil naqli, yaitu al-Quran dan Sunnah, serta sumber hukum Islam yang dzanni atau dalil aqli yaitu ijtihad. ${ }^{12}$

Dalam al-Quran banyak dijelaskan ayatayat hukum yang berkaitan dengan larangan korupsi dalam hukum Islam, salah satunya adalah Ayat Al-Quran yang menunjukkan hukuman bagi pelaku korupsi tersebut adalah firman Allah dalam Q.S al-Maidah ayat 33 yang menjelaskan empat hukuman bagi pelaku korupsi, yaitu dibunuh, disalib, dipotong tangan dan kaki, dan dibuang dari tempat kediamannya. Dalam penerapan hukumanhukuman tersebut terdapat perbedaan pendapat ulama fikih, apakah hukuman itu boleh dipilih atau hukuman yang dikenakan sesuai

\footnotetext{
${ }^{12}$ Fathurrahman Djamil, Filsafat Hukum Islam (Jakarta: Logos Wacana Ilmu. 1997), jilid II, hlm. 9.
}

dengan bentuk tindak pidana yang dilakukan dalam hirabah tersebut.

Kemudian dipertegas pula dengan Q.S. al-Maidah ayat 38 yang menjelaskan jika lakilaki yang mencuri dan perempuan yang mencuri, maka dipotonglah tangan keduanya. sebab turunnya, ayat ini turun pada Thu'mah bin Ubairiq ketika mencuri baju perang milik tetangganya, Qatadah bin An-Nu'man. Baju itu lalu disembunyikan di rumah Zayd bin AsSamin seorang yahudi. Namun terbawa juga kantung berisi tepung yang bocor sehingga tercecerlah tepung itu dari rumah Qatadah sampai ke rumah Zayd. Ketika Qatadah menyadari baju perangnya dicuri, dia menemukan jejak tepung itu sampai ke rumah Zayd. Maka diambillah baju perang itu dari rumah Zayd. Zayd berkata, "Saya diberi oleh Thu'mah". Dan orang-orang bersaksi membenarkannya. Saat itu Rasulullah SAW ingin mendebat Thu'mah, lalu turunlah ayat ini yang menerangkan tentang hukum pencurian.

Mengacu kepada kedua ayat di atas, penulis sependapat dengan sebagian ulama fuqaha yang menjelaskan bahwa hukuman yang dikenakan hendaknya dilakukan secara urut. Hal tersebut sebagaimana yang dicantumkan dalam ayat, serta sesuai dengan bentuk tindak pidana yang dilakukan para pelaku korupsi tersebut. Sebagian lainnya berpendapat bahwa apabila pelaku korupsi tersebut hanya merampas harta, tanpa menyebabkan kematian maka hukumannya adalah dipotong tangan dan kakinya secara silangnya umpamanya tangan kanan dengan kaki kiri.

Jika pelaku korupsi dihubungkan dengan hirabah yang bukan hanya melakukan pembunuhan tetapi juga merampas harta, maka hukumannya adalah dibunuh. Pelaku hirabah ini merampas harta yang disertai dengan pembunuhan, maka menurut mereka, hakim bebas memilih hukumannya, yaitu apakah akan dipotong tangan dan kakinya secara silang kemudian dibunuh atau disalib saja. Ini berbeda dengan korupsi yang disandarkan kepada ghulûl, maka pelaku korupsi bisa dipotong tangannya atau dipenjarakan sesuai dengan kadar kejahatannya. Namun jika pelaku korupsi telah mengganggu keamanan dan stabilitas ekonomi negara, maka hukumannya dapat dipenjarakan seumur hidup atau dikenakan hukum yang ditentukan melalui ta'zîr. Bentuk hukuman ta'zîr tersebut bisa dikenakan dan diserah- 
kan sepenuhnya kepada hakim. ${ }^{13}$ Sedangkan hukuman ta'zîr dalam hukum pidana Islam diposisikan sebagai bentuk hukuman berat kedua setelah qishâsh dan hudud. ${ }^{14}$

Berbeda dengan jarîmah qishâsh dan hudûd, bahwa jarîmah ta'zîr tidak ditentukan banyaknya. Hal ini karena yang termasuk jarîmah ta'zîr ini adalah setiap perbuatan maksiat yang tidak dikenakan hukuman had dan qishâsh, yang jumlahnya sangat banyak. Kaitannya dengan jenis-jenis jarîmah ta'zîr ini Ibn Taimiyah mengemukakan:

$$
\begin{aligned}
& \text { المعاصى التى ليس فيها حد مقدر ولا كفارة كالذى يقبل }
\end{aligned}
$$

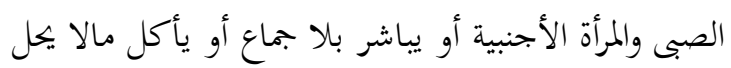

$$
\begin{aligned}
& \text { كالدم والميتة ... فهؤلاء يعاقبون تعزيرا وتنكيلا وتأذيبا بقدر }
\end{aligned}
$$

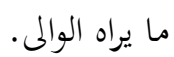

Perbuatan-perbuatan maksiat tidak dikenakan hukuman had dan tidak perlu kifarat, seperti mencium anak-anak (dengan syahwat), mencium wanita lain yang bukan istri, tidur satu ranjang tanpa persetubuhan, atau memakan barang yang tidak halal seperti darah dan bangkai. Maka semuanya di kenakan hukuman ta'zîr sebagai pembalasan dan pengajaran, dengan kadar hukuman yang ditetapkan oleh penguasa. ${ }^{15}$

Tujuan diberikan hak penentuan jarîmah-jarîmah ta'zîr dan hukumannya kepada penguasa adalah agar mereka dapat mengatur masyarakat dan memelihara kepentingan-kepentingannya, sebab bisa menghadapi dengan sebaik-baiknya setiap keadaan yang bersifat mandadak. Jarîmah ta'zîr di samping ada yang di serahkan penentuannya sepe-

\footnotetext{
${ }^{13} T a$ zîr adalah suatu jarimah yang diancam dengan hukuman ta'zîr (selain had dan qishash), pelaksanaan hukuman ta'zîr, baik yang jenis larangannya ditentukan oleh nash atau tidak, baik perbuatan itu menyangkut hak Allah atau hak perorangan, hukumannya diserahkan sepenuhnya kepada penguasa. Hukuman dalam jarimah ta'zîr tidak ditentukan ukurannnya atau kadarnya, artinya untuk menentukan batas terendah dan tertinggi diserahkan sepenuhnya kepada hakim (penguasa).

${ }^{14}$ Lexi Zulkarnaen mengutip Rofiqul 'A'la, Suap Dalam Perspektif Islam, dalam A.S.Burhan dkk, ed, Korupsi Di Negeri. hlm. 182.

${ }^{15}$ Ibn Taymiyyah, Al-Siyâsah al-Syar'iyyah (Cairo: Maktabah Anshâr al-Sunnah al- Muhammadiyyah. 1961), hlm. 112.
}

nuhnya kepada ulil amri, juga ada yang memang sudah ditetapkan oleh syara' (hudûd), akan tetapi syarat-syarat untuk dilaksanakannya hukuman tersebut belum terpenuhi. Misalnya pencurian, yaitu seperempat dinar.

Berdasarkan ayat-ayat hukum di atas, tidak diragukan lagi bagi setiap muslim dapat menegakan hukum pelarangan korupsi sesuai dengan rambu-rambu yang terdapat dalam al-Quran dan Sunnah. Terlebih lagi, apabila disandarkan kepada aspek keyakinan terhadap Islam, maka setiap orang yang tidak berpegang kepada al-Quran dan Sunnah, maka ia dianggap ingkar keislamannya. Artinya, setiap orang yang melakukan korupsi akan dikenai sanksi hukum kerana ia telah keluar dari otoritas hukum sebagai muslim, yakni harus tunduk, taat dan patuh kepada hukum-hukum agama yang dianutnya (alQuran al-Karim).

Selain itu, dalam Sunnah banyak dijelaskan norma-norma hukum pelarangan korupsi dalam hukum Islam, antara lain:

1. Hadits yang diriwayatkan oleh Imam Bukhari dan Ahmad bin Hanbal bahwa Rasulullah SAW bersabda:

$$
\begin{aligned}
& \text { استعمل النبي صلى الله عليه وسلم رجلا من بني أسد يقال } \\
& \text { له بن اللتبية على صدقة فلما قدم قال: هذا لكم وهذا }
\end{aligned}
$$

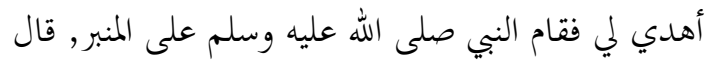

$$
\begin{aligned}
& \text { صفيان أيضا فصعد المنبر فحمد الله وأثنى عليه ثم قال: ما } \\
& \text { بال العامل نبعثه فيأتي فيقول: هذا لك وهذا لي؟ فهلا }
\end{aligned}
$$

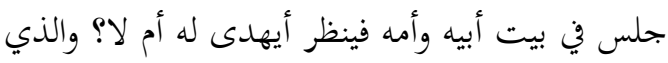

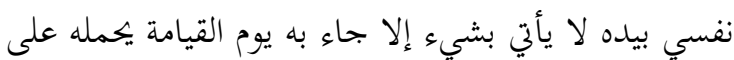

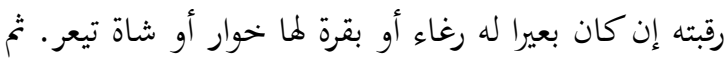

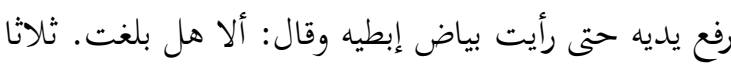

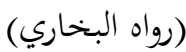

Nabi menugaskan seorang laki-laki dari Bani Asad yang disebut Ibn al-Lutbiyah untuk mengambil zakat, kemudian setelah kembali ia berkata (kepada Nabi): "Ini untuk Tuan dan ini diberikan kepadaku”, kemudian Nabi naik ke mimbar, begitu juga yang dikatakan Sufyan (perawi), kemudian Nabi memuji Allah dan menyanjung-Nya lalu bersabda: "Apaapaan petugas ini, aku utus kembali seraya 
berkata, "ini untukmu dan ini untukku?" maka cobalah ia duduk (saja) di rumah orang tuanya (tidak menjadi petugas) dan mengandaikan ia diberi hadish atau tidak? Demi Zat yang diriku berada di tangan-Nya, maka ia tidak mendapat apa-apa kecuali datang di hari kiamat dengan memikul di atas leher, kalaupun berupa unta, sapi atau kambing yang semuanya meringikik." Kemudian Nabi mengangkat tangannya sampai kulihat putihnya ketiak beliau (kata rawi) dan bersabda: "bukankah telah aku sampaikan?" diulanginya tiga kali. (H.R. Bukhari). ${ }^{16}$

$$
\text { وسلم قال: هن هيد الساعدي العمال غلن رسول الله صلى الله عليه }
$$

Dari Abî Hamid al-Saidy sesungguhnya Rasulullah saw bersabda: Hadiah-hadiah pada pejabat adalah ghulûl (pengkhianatan) (H.R. Ahmad). ${ }^{17}$

Menurut kepada ketentuan hadits tentang ghulûl di atas, tampak jelas bahwa korupsi merupakan tindakan pidana yang bertentangan dengan hukum syara'.

2. Hadits dari Abi Hurairah r.a. yang diriwayatkan oleh Turmudzi bahwa Rasulullah SAW telah bersabda:

$$
\text { وسلم البراشي والمرتشي في الحسكم (رواه الترمذي) لعن الله عليه }
$$

Dari Abu Hurairah ra. Berkata: Rasulullah melaknat orang yang menyuap dan yang menerima suap dalam hukum (H.R. Turmuzi). ${ }^{18}$

Mengacu kepada hadits di atas, risywah atau suap memang tidak bisa terjadi dari satu pihak. Ia selalu melibatkan kedua belah pihak, bahkan sangat boleh jadi bisa tiga pihak. Yakni si penyuap (râsyî), yang disuap atau yang menerima suap (murtasyii) dan yang menjadi perantara (râysy). Oleh sebab itu, risywah ini memang merupakan kejahatan yang terorganisir. Sekaligus ia merupakan kejahatan yang susah dibongkar, karena t.th.).

${ }^{16}$ Al-Bukhari, Shahih al-Bukhari (Beirut: Dar al-Fikr.

${ }^{17}$ Ahmad bin Hanbal, Al-Musnad (Beirut: Dar alFikr. t.th.).

${ }^{18}$ Al-Turmudzi, Sunan Tirmidzi (Beirut: Dar al-Fikr. t.th.). antara pelaku dan korban sama-sama terlibat. Beda dengan kejahatan umumnya, pencurian, penipuan atau penganiayaan; pelaku dan korban tidak mungkin bersekongkol.

3. Hadits riwayat Ibnu Hibban yang menjelaskan bahwa Rasulullah SAW bersabda:

$$
\text { الله علن عبد الله بن عمرو قال : سمعت رسول الله صلى }
$$

Dari Abdullah ibn Amru berkata: Saya mendengar Rasulullah saw. bersabda: Allah melaknat orang yang menyuap dan yang menerima suap. (H.R. Ibnu Hibban). ${ }^{19}$

Menurut ketentuan hadits di atas, jika seseorang untuk mengerjakan sesuatu pekerjaan telah dibayar maka apapun selain itu bukan menjadi haknya dan haram mengambilnya. Begitu juga, jika dia memanfaatkan harta perusahaan atau negara untuk kepentingan pribadinya, dalam hal ini ia telah mengambil sesuatu yang bukan haknya secara bathil dan haram hukumnya.

Beberapa petikan hadits di atas juga dapat menjadi dasar bagi pelarangan korupsi dalam hukum Islam. Selebihnya praktik pelarangan korupsi dalam hukum Islam hendaknya ditujukan sesuai dengan tujuan syari'at (maqâshid al-syarî́at). Sedangkan untuk menjelaskan lebih rinci tentang bagaimana mengimplementasikan pelarangan korupsi dalam hukum Islam tentu diperlukan pengkajian lebih dalam melalui proses penetapan hukum (istinbath al-ahkam).

Tujuan utama penetapan dan penerapan sanksi pidana Islam kepada pelaku korupsi sekarang ini sepertinya tidak mapan lagi, mengingat perbuatan korupsi dilakukan tanpa rasa takut dan mengabaikan aturanaturan yang ada. Untuk melakukan pencegahan dan perbaikan atau pendidikan bagi perbuatan korupsi sebagai wujud untuk mengurangi kejahatan dan benar-benar akan mencapai tujuannya, dalam khazanah pemikiran hukum pidana Islam, syarat pada jarîmah itu

\footnotetext{
${ }^{19}$ Hadist riwayat Muslim dan Baihaqi sebagaimana dikutip dari kitab Al-Mughni VII/459, Syarah AlKabir 'Alal Muqni' VII/348 dan Al-Hidayah ma'a Takmilah Fathul Qadir X/26.
} 
dikembangkan, yaitu: ${ }^{20}$ menjerakan si pelaku; dapat menjadi pelajaran bagi orang lain; seimbang dengan jarîmah yang dilakukan; dan bersifat umum dan atau berlaku terhadap semua orang. Meskipun demikian, persoalan yang patut diperhatikan adalah tidak semua jarîmah ${ }^{21}$ atau kejahatan yang diancam pidana sebagaimana ditentukan dalam al-Quran dan hadîth Nabi Saw. Karena motivasi kejahatan juga harus diperhatikan, termasuk kejahatan korupsi apabila dikategorikan kepada jarîmah ta'zîr. Begitupun dengan ancaman pidana hudûd, jika dalam kejahatan korupsi itu mengandung unsur syubhat (keraguan), maka sanksinya tidak diberlakukan, sesuai prinsip:

$$
\text { إدرأوا الحدود با لشبها ت. }
$$

Hindarilah hudûd apabila terdapat keraguan. ${ }^{22}$

Selain itu, dalam pidana Islam mempertegas lagi bahwa suatu jarîmah tidak dapat diterapkan apabila nash yang menegaskannya tidak ada. Sesuai dengan kaidah hukum Islam, yaitu:

$$
\text { لاجريمة ولاعقوبة بلا نص الا فن غلول. }
$$

Tidak ada jarîmah dan tidak pula ada sanksi tanpa ada nașh kecuali dalam ghulûl. ${ }^{23}$

Ketentuan di atas menunjukkan bahwa apabila hukuman hudûd tidak dapat diterapkan, maka ulama fiqih menetapkan hukuman yang akan dilaksanakan adalah hukuman ta'zîr, sesuai dengan kadar kemaslahatan

\footnotetext{
${ }^{20}$ Ahmad Azhar Basyir, Ikhtisar Fikih Jinayat (Hukum Pidana Islam) (Yogyakarta: UII Press. 2001), hlm. 66.

${ }^{21}$ Larangan-larangan syara' yang diancam Allah dengan hukuman had atau ta'zîr.

${ }^{22}$ Abû Yûsuf, Al-Râd 'Alâ Siyâr al-Awzâ'î (Mesir: Lajnah Iḥyâ al-Ma'ârif al-Nu'mâniyyah. 1357), hlm. 50. Al-Suyûtịi, Al-Asybah wa al-Nazâir fi al-Furû' (Surabaya: Makatabah Dâr Ihyâ' al-Kutub al-'Arâbiyyah, t.th.), juz I, hlm. 14.

${ }^{23}$ Kaidah tersebut merupakan penyederhanaan yang dilakukan oleh 'Abd. al-Qadîr 'Awdah dari kaidah yang terdapat dalam kitab al-Badâ'i, yaitu: ( لاحكم لأفعال (العقلاء قبل النص Lihat Jalâl al-Dîn 'Abd al-Raḥmân Ibn Abî Bakr al-Suyûthî, Al-Asybah wa al-Nazâir fi Qawâ'id alFurû' Fiqh al-Syâfi'iyyah (Bairût: Dâr al-Kutub al-'Arabî. 1987), hlm. 133. Dan Muhammad Abû Zahrah, Al-Fiqh alIslâmî (Cairo: Jam‘iyyah al-Dirâsat al-Islâmiyyah, t.th.), hlm. 195.
}

yang dikehendaki. Sesuai kaidah hukum yang berbunyi: ta'zîr sangat tergantung kepada tuntutan kemaslahatan (التعزير يدور مع المصلحة ). Dalam hal ini ukuran kemaslahatan sudah sesuai dengan persyaratan kemaslahatan yang ada dalam ushûl fiqh ${ }^{24}$.

Kalangan ulama fiqh tidak memberikan aturan yang tegas mengenai ada tidaknya hak kepala negara untuk memberikan grasi kepada pelaku tindak pidana jenis ta'zîr, akan tetapi dalam konteks sekarang hak memberikan grasi oleh kepala negara dirasa perlu oleh masyarakat dengan mempertimbangkan dan diijtihadkan. Dalam konteks ini, penulis sependapat dengan pendapat Juhaya $\mathrm{S}$. Praja bahwa untuk menjamin penegakan hukum dalam pemberantasan tindak pidana korupsi melalui teori ta'zîr hendaknya mengacu kepada kaidah hukum yang berbunyi: ada kemungkinan menerapkan sanksi pidana tanpa ada nașh dalam perkara ghulûl untuk tujuan kemaslahatan ( امكان العقبة بلا نص فن الغلول (لمصلمة ().

Oleh karena itu, penguasa/pemerintah (wali al-amr) berkewenangan untuk menentukan sanksi ta'zîr. Pelaksanaannya tidaklah berpegang pada satu jenis hukuman, karena ia terkait dengan unsur kemaslahatan yang harus diperhatikan. Namun dalam pelaksanaan sanksi, penguasa dapat menyerahkan kepada lembaga peradilan (peran hakim) sebagai lembaga yang berkompeten untuk menjatuhkan sanksi itu. la dapat menentukan suatu hukum yang menurut ijtihadnya dapat memberikan pengaruh preventif, repretif, kuratif dan edukatif terhadap pelaku jarîmah dengan mempertimbangkan keadaan pelaku, jarîmah, korban kejahatan, waktu dan tempat kejadiannya.

Korupsi merupakan tindakan pidana yang dianggap melawan hukum, yakni ada unsur-unsur dari suatu delik secara terangterangan atau diam-diam dianggap mengandung delik hukum, sebagaimana diartikan

\footnotetext{
${ }^{24}$ Kemaslahatan yang dimaksudkan dalam ushûl figh adalah mencakup kemaslahatan umum dan kemaslahatan khusus. Wahbah al-Zuhailî, Ushûl al-Fiqh al-Islâmî (Bairût: Dâr al-Fikr. 2004), juz II, hlm. 1056. Lihat pula Mukhtar Yahya dan Fatchur Rahman, Dasar-Dasar Pembinaan Fiqh Islam (Bandung: Al Ma'arif. 1986), cet. I, hlm. 105.
} 
dalam makna yang luas, yaitu: pertama, lebih mudah menerima pandangan sifat melawan hukum materil; kedua, sifat melawan hukum merupakan elemen tetap dari tiap-tiap delik meskipun tidak disebutkan dalam rumusan; ketiga, dapat mengakui pengecualian sebagai penghapusan sifat melawan hukum di luar undang-undang atau hukum positif tidak tertulis; keempat, untuk mengadakan pembuktian melawan hukum oleh penuntut umum, hanyalah apabila dalam rumusan suatu delik dirumuskan dengan tegas; dan kelima, apabila elemen melawan hukum tidak dirumuskan dalam suatu delik, maka tidak perlu dibuktikan, kecuali menurut pandangan hakim ada keragu-raguan unsur tersebut sehingga di dalam sidang atas inisiatif pimpinan dicari pembuktiannya elemen melawan hukum tersebut.

Oleh karena itu, penulis merumuskan bahwa korupsi jelas-jelas merupakan suatu tindakan pidana yang dilarang, baik dalam hukum Islam maupun hukum positif. Adanya dasar hukum pelarangan korupsi juga dapat disebabkan perbuatan tersebut bisa merugikan orang banyak dan dapat merusak tatanan sosial, politik, hukum, dan ekonomi suatu bangsa. Kemudian dalam hal pembuktian delik hukum pelarangan korupsi dapat diketahui dari adanya unsur-unsur melawan hukum dapat dibuktikan di persidangan. Apabila unsur-unsur melawan hukum tidak terpenuhi dan tidak terbukti atas delik yang dituduhkan, maka seseorang dapat dibebaskan dari segala tuduhan korupsi.

\section{Penerapan Sanksi Pidana Ta'zîr Bagi Ko- ruptor di Indonesia}

Konseptualisasi transformasi normanorma hukum ta'zîr ke dalam konstitusi dan undang-undang hendaknya mengikuti prosedur konstitusional dan sejalan dengan norma hukum serta cita hukum dalam politik hukum di Indonesia. Pendek kata, politik hukum di Indonesia seperti telah dilakukan dalam proses kodifikasi dan unifikasi hukum Islam melalui penyusunan rancangan undang-undang hukum pidana ta'zîr, yang bertujuan penegakan hukum (law enforcement).

Kedua, Pendekatan Institusional. Pendekatan institusional merupakan suatu proses penjabaran norma-norma hukum yang ada dalam bentuk produk peraturan dan perundang-undangan menjadi pranata-pranata hukum Islam. Secara sederhananya, pendekatan semacam ini dilakukan dengan cara membentuk institusi-institusi baik pemerintah maupun masyarakat yang akan memperkuat penegakan hukum Islam di masyarakat. Maka salah satu cara yang paling efektif untuk menegakan hukum Islam adalah merepresentasikan tanggungjawab negara dengan membentuk pranata hukum Islam.

Seperti telah penulis jelaskan pada babbab sebelumnya, institusionalisasi hukum Islam dapat difahami dalam dua pengertian: pertama, ia merupakan suatu upaya untuk mentransformasikan ide-ide dan gagasan-gagasan bagi pembentukan suatu pranata hukum Islam; kedua, ia merupakan proses aktualisasi ide-ide atau gagasan-gagasan menjadi institusi atau pranata hukum Islam, termasuk pula kedudukan, tugas, dan fungsinya dalam proses penegakan hukum Islam itu sendiri.

Dalam sudut pandang ideal, makna institusionalisasi hukum pidana Islam mencerminkan mata rantai sejarah pemikiran hukum pidana Islam dalam studi Ilmu Hukum Pidana Islam (Fiqh al-Jinayah) yang dimulai dari pemikiran tentang sumber-sumber, prinsipprinsip, asas-asas dan metode hingga pada tingkat pembentukan peraturan dan perundang-undangan hukum Islam. Maksud dari institusionalisasi hukum Islam di sini adalah menyusun berbagai regulasi (peraturan dan undang-undangan) yang memadai di bidang hukum Islam, mulai dari menggaransinya ke dalam konstitusi negara hingga membentuk peraturan turunannya dan dijabarkan menjadi institusi atau pranata hukum Islam. Hal ini sebagaimana telah dijelaskan penulis pada bagian pendekatan konstitusional.

Jika dikaitkan dengan konsep taqnin hukum ta'zîr dalam pidana Islam dan hubungannya dengan politik hukum di Indonesia, hukum Islam tampaknya sangat akomodatif dalam menyikapi perubahan sosial, politik, dan hukum masyarakat. Hasbi Ash-Shiddiqiey, ${ }^{25}$ misalnya telah mengatakan bahwa hu-

\footnotetext{
${ }^{25}$ Hasbi As-Shiddiqiey, Dinamika dan Elastisitas Hukum Islam (Jakarta: Tintamas. 1975), hIm. 27.
} 
kum Islam pada sudut keberlakuannya bersifat progressif dan dinamis. Selain itu, berlakunya hukum Islam harus ditekankan pada aspek-aspek kemaslahatan yang bersifat umum dan tidak hanya menyangkut kepentingan golongan Islam semata.

Oleh karena itu, di samping hukum Adat dan hukum Eropa memberikan pengaruh besar dalam arah perkembangan hukum Islam, hukum Islam pun telah memberikan warna tersendiri dalam kontritusi dan ketatanegaraan, serta menjadi nilai-nilai dan normanorma yang menyatu dengan tradisi dan politik hukum di Indoensia. Konsep hukum Islam yang didasarkan pada nilai-nilai etika dan moral akan lebih memberi tempat bagi setiap orang untuk mencapai tujuan hidupnya sesuai dengan nilai-nilai kebebasan dalam politik hukum itu sendiri. Terutama dalam realitas sosial yang secara kuantitatif mayoritas berpenduduk muslim, sangat memungkinkan hukum Islam bersinergi memberikan warna di dalam konstitusi Indonesia.

Ketiga, Pendekatan Kultural. Syari'ah memiliki masa depan yang paling penting dalam masyarakat dan komunitas Islam karena peran fundamentalnya dalam sosialisasi, penghormatan terhadap pranata-pranata dan hubungan-hubungan sosial, serta pembentukan dan pengembangan nilai-nilai dasar tersebut, semua itu diterjemahkan ke dalam perundang-undangan umum serta kebijakan publik melalui proses politik yang demokratis.

Namun demikian, penerapan hukum Islam (syariah) yang tidak dinamis jelas tidak akan memiliki masa depan, karena ia hanya dipandang sebagai sistem normatif, yang bila dibuat dan diselenggarakan secara formal oleh negara akan melahirkan konflik dari pihak-pihak yang menolak syari'at Islam. Klaim bisa saja dibuat untuk mengatakan bahwa suatu kebijakan atau hukum adalah syariah, tapi klaim itu akan selalu salah karena hal itu tidak lebih dari sebuah usaha menggunakan kesucian Islam untuk kepentingan politik elit penguasa.

Oleh karena itu, penerapan sanksi pidana ta'zîr bagi pelaku korupsi di Indonesia melalui pendekatan teori ta'zîr (nazhariyyah al-ta'zîr) dilakukan secara bertahap. Tahapan yang dimaksud adalah meningkatkan pe- mahaman, mendorong, dan menganjurkan masyarakat untuk melakukan perbuatan ma'ruf (baik) serta perbuatan munkar dan segala macam kemadharatan. Demikian halnya untuk mencapai tujuan pokok hukum Islam adalah mendatangkan, mendapatkan, dan memelihara kemaslahatan bagi manusia. Pendek kata, penerapan sanksi pidana ta'zîr bagi pelaku tindak pidana korupsi melalui pendekatan teori ta'zîr (nazhariyyah al-ta'zîr) hendaknya membawa kepada kemaslahatan umum.

Adapun penerapan sanksi pidana ta'zîr bagi pelaku korupsi melalui pendekatan teori ta'zîr (nazhariyyah al-ta'zîr), selanjutnya dapat diupayakan dilakukan melalui tiga strategi sebagai berikut:

1. Strategi Preventif

Strategi ini harus dibuat dan dilaksanakan dengan diarahkan pada hal-hal yang menjadi penyebab timbulnya korupsi. Setiap penyebab yang terindikasi harus dibuat upaya preventifnya, sehingga dapat meminimalkan penyebab korupsi. Disamping itu perlu dibuat upaya yang dapat meminimalkan peluang untuk melakukan korupsi dan upaya ini melibatkan banyak pihak dalam pelaksanaanya agar dapat berhasil dan mampu mencegah adanya korupsi.

2. Strategi Deduktif

Strategi ini harus dibuat dan dilaksanakan terutama dengan diarahkan agar apabila suatu perbuatan korupsi terlanjur terjadi, maka perbuatan tersebut akan dapat diketahui dalam waktu yang sesingkat-singkatnya dan seakurat-akuratnya, sehingga dapat ditindaklanjuti dengan tepat. Dengan dasar pemikiran ini banyak sistem yang harus dibenahi, sehingga sistem-sistem tersebut akan dapat berfungsi sebagai tata aturan yang cukup tepat memberikan sinyal apabila terjadi suatu perbuatan korupsi. Hal ini sangat membutuhkan adanya berbagai disiplin ilmu baik itu ilmu hukum, ekonomi maupun ilmu politik dan sosial.

\section{Strategi Represif}

Strategi ini harus dibuat dan dilaksanakan terutama dengan diarahkan untuk memberikan sanksi hukum yang setimpal secara cepat dan tepat kepada pihak-pihak yang terlibat dalam korupsi. Dengan dasar pemikiran 
ini proses penanganan korupsi sejak dari tahap penyelidikan, penyidikan dan penuntutan sampai dengan peradilan perlu dikaji untuk dapat disempurnakan di segala aspeknya, sehingga proses penanganan tersebut dapat dilakukan secara cepat dan tepat. Namun demikian pada tahap implementasinya tentu harus dilakukan secara terintregasi dan sistematis.

Oleh karena itu, pemerintah dalam hal ini harus memiliki komitmen politik yang lebih kuat, menerapkan strategi yang lebih sistematis dan komprehensif. Selain itu, juga perlu dirumuskan berbagai kebijakan yang lebih fokus dan konsolidatif untuk mendorong dan meningkatkan program percepatan pemberantasan korupsi di Indonesia. Peneliti dapat mengatakan di sini bahwa pemberantasan korupsi di Indonesia melalui penerapan sanksi pidana ta'zîr memerlukan peran serta ulama, ahli hukum, pemerintah, parlemen, dan aparatur penegak hukum itu sendiri. Alasannya, bukan hal yang mudah merubah suatu tradisi hukum lama menjadi tradisi hukum baru. Salah satu strategi yang paling memungkinkan adalah harus dimulai dari kekuasaan itu sendiri, tepatnya dari eksekutif, legislatif, dan yudikatif.

\section{E. Penutup}

Pada bagian penutup ini, penulis merumuskan beberapa pokok pikiran sebagai berikut: pertama, tahapan penerapan sanksi pidana ta'zîr menurut nazhariyyah al-ta'zîr dan Undang-Undang Nomor 20 Tahun 2001 bukan hanya bertujuan untuk cita-cita ideal dan kesadaran hukum masyarakat yang perlu ditransformasikan ke dalam peraturan perundang-undangan, tetapi juga untuk penegakan hukum dan keadilan; kedua, penerapan sanksi pidana ta'zîr menurut nazhariyyah al-ta'zîr) dan Undang-Undang Nomor 31 Tahun 1999 Jo Undang-Undang Nomor 20 Tahun 2001 dapat dilakukan dengan cara mengamandemen atau memasukkan sanksi pidana ta'zîr ke dalam perundang-undangan korupsi di Indonesia; dan ketiga, penerapan sanksi pidana ta'zîr di Indonesia menurut teori (nazhariyyah al-ta'zîr) dan Undang-Undang Nomor 20 Tahun 2001 hendaknya didukung dengan kesadaran hukum masyara- kat dan pemerintah serta konsistensi aparatur penegak hukum pada khususnya.

\section{Daftar Pustaka}

Abû Zahrah, Muhammad. t.th. Al-Fiqh alIslâmî. Cairo: Jam‘iyyah al-Dirâsah al-Islâmiyyah.

Admin. http://zanikhan.multiply.com/journal/item/694/694, diakses tanggal 18 Oktober 2012.

Ahmad bin Hanbal. t.th. Al-Musnad. Beirut: Dâr al-Fikr.

As-Shiddiqiey, Hasbi. 1975. Dinamika dan Elastisitas Hukum Islam. Jakarta: Tintamas.

Azhar Basyir, Ahmad. 2001. Ikhtisar Fikih Jinayat (Hukum Pidana Islam). Yogyakarta: UII Press.

Azyumardi Azra. Agama dan Pemberantasan Korupsi. artikel dalam http://www.kompas.com/kompas-cetak/0309/05/opini/542015.htm, diakses pada tanggal 16 Desember 2009.

Bukhari, al-. t.th. Shahih al-Bukhari. Beirut: Dâr al-Fikr.

Burhan, A.S. dkk. 2004. Korupsi di Negeri Kaum Beragama; Ikhtiah Membangun Figh Anti Korupsi. Jakarta: P3M dan Kemitraan Partnership.

Chazawi, Adami. 2005. Hukum Pidana Materiil dan Formiil Korupsi di Indonesia. Malang: CV. Bayu Media.

Djamil, Fathurrahman. 1997. Filsafat Hukum Islam. Jakarta: Logos Wacana Ilmu.

Editor. 2000. Webster's Third New International Dictionary. USA: Webster University Press.

Hamzah, Andi. 2005. Pemberantasan Korupsi Melalui Hukum Nashional dan Internashional. Jakarta: PT. Raja Grafindo Persada.

Jalâl al-Dîn 'Abd al-Rahmân Ibn Abî Bakr alSuyûțî. 1987. Al-Asybah wa al-Nazâir fi Qâwî̀id al-Furû' Fiqh al-Syâfi'iyyah. Bairūt: Dâr al-Kutub al-'Arabî.

Koran Tempo. Pemberantasan Korupsi dari Masa ke Masa. Edisi Kamis, 18 Desember 2003, dan http://www.tempointeraktif.com/hg/narasi/2004/10/25/nrs, 2004102501,id.html, diakses tanggal 16 Desember 2009. 
Lexi Zulkarnaen Hikmah. Korupsi Perspektif Hadits. artikel dalam http://www. Kommabogor.wordpress.com/2008/01/13/kor upsi-perspektif-hadis/, diakses pada tanggal 28 Maret 2010.

M. Echols, John dkk. 2003. Kamus Inggris Indonesia; An English-Indonesian Dictionary. Jakarta: Gramedia.

Poerwadarminta, W.J.S. 2001. Kamus Besar Bahasa Indonesia. Jakarta: Balai Pustaka.

Suyûțî, al-. t.th. Al-Asybah wa al-Nazấir fi alFurû'. Surabaya: Makatabah Dâr Ihyâ' alKutub al-'Arâbiyyah.
Taymiyyah, Ibn. 1961. Al-Siyâsah al-Syar'iyyah. Cairo: Maktabah Anshâr al-Sunnah alMuhammadiyyah.

Turmudzi, al-. t.th. Sunan Tirmidzi. Beirut: Dâr al-Fikr.

Wardi Muslich, Ahmad. 2004. Hukum Pidana Islam. Jakarta: PT. Sinar Grafika.

Yahya, Mukhtar dkk. 1986. Dasar-Dasar Pembinaan Figh Islam. Bandung: Al-ma'arif.

Yūsuf, Abû . 1357. Al-Râd 'Alâ Siyâr al-Awzâ'î. Mesir: Lajnah Ihyâ al-Ma'ârif al-Nu’mâniyyah.

Zuhaylî, Wahbah, al-. 2004. Ushûl al-Figh alIslâmî. Bairūt: Dâr al-Fikr. 